\title{
Effect of nickel precursor and catalyst activation temperature on methanation performance
}

\author{
Battulga Buyan-Ulzii, Odbayar Daariimaa, Chuluunsukh Munkhdelger, Galindev Oyunbileg \\ Byambajav Enkhsaruul* \\ Laboratory of Clean Energy Technology Development, School of Arts \& Sciences, National University of Mongolia, \\ Ulaanbaatar 14200, Mongolia
}

*Corresponding author: enkhsaruul_b@num.edu.mn; ORCID ID:0000-0001-7725-1105

Received:05 Nobember 2018; revised:22 December 2018; accepted: 04 January 2019

\begin{abstract}
This work studied an effect of anionic precursor on the preparation of active and fine nickel metal catalysts for syngas methanation. Nickel catalysts were prาepared by impregnation-co-precipitation method. Nickel hydrate salts of $\mathrm{Ni}\left(\mathrm{NO}_{3}\right)_{2} \cdot 6 \mathrm{H}_{2} \mathrm{O}, \mathrm{NiSO}_{4} \cdot 6 \mathrm{H}_{2} \mathrm{O}$ and $\mathrm{NiCl}_{2} \cdot 6 \mathrm{H}_{2} \mathrm{O}$ were used as a metal catalyst precursor, and the obtained catalysts were named as $\mathrm{Ni} / \mathrm{Al}(\mathrm{N}), \mathrm{Ni} / \mathrm{Al}^{2}(\mathrm{~S})$ and $\mathrm{Ni} / \mathrm{Al}^{2}(\mathrm{Cl})$, respectively. Methanation synthesis of carbon monoxide was carried out in a fixed bed stainless reactor. Prior to experiment, the catalyst powder was pressed into tablets, then crushed and sieved to use $0.5-0.9 \mathrm{~mm}$ particles. Reactions were performed at the temperature of $350{ }^{\circ} \mathrm{C}$ in the pressure of $3 \mathrm{~atm}$ of $\mathrm{H}_{2}: \mathrm{CO}$ syngas (the molar ratio of $3: 1$ ) with the GHSV of $3000 \mathrm{~h}^{-1}$. In the present methanation conditions, the Ni/Al (N), Ni/Al (S) and $\mathrm{Ni} / \mathrm{Al}(\mathrm{Cl})$ catalysts gave the $\mathrm{CH}_{4}$ selectivity of $93 \%, 18 \%$ and $91 \%$ (vol.), respectively. The XRD and ICP-OES analysis clarified that although the $\mathrm{Ni} / \mathrm{Al}(\mathrm{S})$ catalyst contained a similar nickel amount of $17.4 \mathrm{wt} \%$ to other two catalysts, its metal distribution was poor. Also the low activity of the $\mathrm{Ni} / \mathrm{Al}$ (S) catalyst was caused by the contamination of remained sulfur from sulfate precursor. This work also examined an influence of catalyst activation temperature pre-synthesis. The $\mathrm{Ni} / \mathrm{Al}(\mathrm{N})$ catalyst was reduced by pure hydrogen gas at different temperatures of $350^{\circ} \mathrm{C}, 400^{\circ} \mathrm{C}$ or $450^{\circ} \mathrm{C}$. The catalyst activated at $400^{\circ} \mathrm{C}$ produced the highest $\mathrm{CH}_{4}$ amount of $0.087 \mathrm{mmol} \cdot \mathrm{g}^{-1}$ cat for the duration of $1 \mathrm{~h}$ methanation. An initial temperature of methane formation was the lowest for the $\mathrm{Ni} / \mathrm{Al}(\mathrm{N})$ catalyst which was activated at $400{ }^{\circ} \mathrm{C}$ among three catalysts.
\end{abstract}

Keywords: CO hydrogenation, anions of nickel precursors, catalyst reduction

\section{INTRODUCTION}

World energy committee reported a strategy of global energy application and structure till 2035. It was known in the report that energy coal and petroleum consumption would be decreased by 0.7 billion tons and 0.5 billion tons, respectively; however natural gas consumption would increase by 1560 billion $\mathrm{m}^{3}$ in target year. Many developed countries accepted the natural gas as their primary energy source [1-3]. Consequently, a need for natural gas production and import increased significantly in many countries. In spite of huge deposits of energy coal, Mongolia has no resource of natural gas excluding coal bed methane. Generally, lignite calorie is estimated approximately by $16-24 \mathrm{MJ} \cdot \mathrm{kg}^{-1}$, however natural gas generates 2 times higher calorie compared to lignite $[1,2]$. Besides its low caloric value, lignite has disadvantage to utilize it as a fuel in populated city, and becomes a source of toxic emission and environmental pollution [3]. Therefore, our country has the necessity of producing substitute natural gas (SNG) in order to meet increasing energy demand and environmental regulations. A research on methanation is important not only because of the increase need of a high caloric fuel, but also because of clean fuel utilization [5-13]. We clarified an efficient method of impregnation-coprecipitation to prepare nickel catalyst of methanation in our previous study [4]. In the present study, we aimed to examine an effect of metal precursor, which was used in impregnation-co-precipitation to prepare a nickel catalyst, on methanation activity of carbon monoxide. Also this research work had a purpose to clarify an influence of activation temperature of nickel catalyst prior to catalyst evaluation test on $\mathrm{CO}$ conversion and methane selectivity. 


\section{EXPERIMENTAL}

Catalyst preparation: Impregnation-co-precipitation method was applied to load nickel precursor onto $\gamma-\mathrm{Al}_{2} \mathrm{O}_{3}$. Reagents used as a precursor solution of nickel metal were nickel (II) nitrate hexahydrate $\mathrm{Ni}\left(\mathrm{NO}_{3}\right)_{2} \cdot 6 \mathrm{H}_{2} \mathrm{O}$, nickel (II) sulfate hexahydrate $\left(\mathrm{NiSO}_{4} \cdot 6 \mathrm{H}_{2} \mathrm{O}\right)$ and nickel (II) chloride hexahydrate $\left(\mathrm{NiCl}_{2} \cdot 6 \mathrm{H}_{2} \mathrm{O}\right)$. The corresponding catalysts were described as $\mathrm{Ni} / \mathrm{Al}(\mathrm{N}), \mathrm{Ni} / \mathrm{Al}(\mathrm{S})$ and $\mathrm{Ni} / \mathrm{Al}(\mathrm{Cl})$. Nominal nickel contents were $20 \mathrm{wt} \%$ for every catalyst. The precipitation by sodium carbonate was done at $50{ }^{\circ} \mathrm{C}$ with a continuous stirring. The precipitate was filtrated using by a Buchner funnel, and washed three times by distilled water. The obtained samples were dried at $110^{\circ} \mathrm{C}$ for $12 \mathrm{~h}$, and calcined at $500^{\circ} \mathrm{C}$ for $1 \mathrm{~h}$, and reduced at $350^{\circ} \mathrm{C}, 400{ }^{\circ} \mathrm{C}$ or $450{ }^{\circ} \mathrm{C}$ in $100 \% \mathrm{H}_{2}$ gas flow with a rate of $13 \mathrm{ml} \cdot \mathrm{min}^{-1}$. All catalyst powder were molded, then crushed and sieved to prepare particle size between 0.5 and $0.9 \mathrm{~mm}$ in diameter.

Catalytic activity test: Catalytic activity was measured by a fixed bed stainless tubular reactor $(8 \mathrm{~mm}$ in inner diameter). The catalyst was placed in the mid of tubular reactor, and about $1 \mathrm{~g}$ of catalyst was used in every experiment. After the activation treatment by $100 \% \mathrm{H}_{2}$ with a flow rate of $13 \mathrm{ml} \cdot \mathrm{min}^{-1}$, the reducing gas was switched by a mixture gas of $\mathrm{H}_{2}$ and $\mathrm{CO}$ (molar ratio of $3: 1$ ) with a flow rate of $50 \mathrm{ml} \cdot \mathrm{min}^{-1}$, and synthesis pressure was collected until $3 \mathrm{~atm}$ by the regulation valve of BPR.

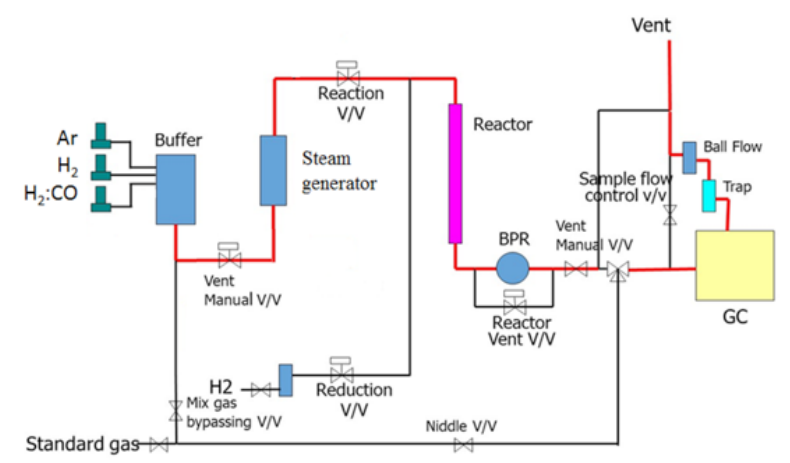

CO conversion, methane selectivity and yield were calculated by the next equations:

CO conversion:

$X_{C O}(\%)=\frac{V_{C O_{\text {inist }}-V_{C O_{\text {outiet }}}}}{V_{C O_{\text {inist }}}} \times 100$

Methane selectivity:

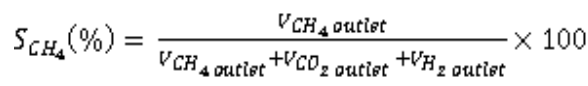

Methane yield:

$Y_{C H_{4}}(\%)=\frac{X_{C O} \times S_{C H_{4}}}{100}$

Scheme 1. Fixed bed reactor system of methanation synthesis
Catalyst evaluation tests were carried out at $350{ }^{\circ} \mathrm{C}$ for $1 \mathrm{~h}$. The value of GHSV was $3000 \mathrm{~h}^{-1}$. Composition of outlet gases were analyzed using a gas chromatograph equipped with a TCD (YL6100 GC) every 5 min of reaction. Fixed bed reactor system of methanation synthesis was illustrated in Scheme 1.

Catalyst characterization: X-ray diffraction patterns of fresh and used catalysts were recorded using a diffractometer (XRD mini Flex 600) employing with Co $\mathrm{Ka}$ radiation $(40 \mathrm{kV}, 30 \mathrm{~mA})$. The diffraction angle was selected from $5^{\circ}$ to $70^{\circ}$ with a scan rate of $5^{\circ} \mathrm{min}^{-1}$ and step size of $0.01^{\circ}$.

BET surface area was measured using by Flowsorb III $2305 / 2310$. Nitrogen adsorption was done in pressure of $88.9 \mathrm{MPa}$ at the temperature of $77 \mathrm{~K}$ in $\mathrm{N}_{2}$ flow with a rate of $53 \mathrm{ml} \cdot \mathrm{min}^{-1}$. Approximately $10 \mathrm{mg}$ of catalyst sample was loaded in a glass tube and outgassed at $150{ }^{\circ} \mathrm{C}$ for $1 \mathrm{~h}$ in a $\mathrm{N}_{2}$ gas flow. Nickel contents in fresh catalysts were determined using by a method of ICPOES (ICP-OES6500).

\section{RESULTS AND DISCUSSION}

Effect of nickel catalyst precursor on catalytic activity of methanation: After the impregnation-coprecipitation, actual contents of nickel catalysts were measured using by a method of ICP-OES. It was identified that when nickel content of the catalysts was nominally expected as $20 \mathrm{wt} \%$, the obtained contents were between in approximately 17 - 19 wt \% depending on primary anion type of metal precursors. Table 1 shows the nominal and experimental contents of nickel metal precipitated by the impregnation-co-precipitation method using different anion precursors.

Table 1. Contents of nickel metal precipitated by an impregnation-co-precipitation method using different anion precursors

\begin{tabular}{ccc}
\hline Catalyst & \multicolumn{2}{c}{ Ni content, wt \% } \\
\cline { 2 - 3 } code & Nominal & Experimental $^{*}$ \\
\hline $\mathrm{Ni} / \mathrm{Al}(\mathrm{N})$ & 20.0 & 16.6 \\
$\mathrm{Ni} / \mathrm{Al}(\mathrm{S})$ & 20.0 & 17.4 \\
$\mathrm{Ni} / \mathrm{Al}(\mathrm{Cl})$ & 20.0 & 18.5 \\
\hline
\end{tabular}

${ }^{*}$ Determined by ICP-OES analysis

Fresh catalysts of $\mathrm{Ni} / \mathrm{Al}(\mathrm{N}), \mathrm{Ni} / \mathrm{Al}(\mathrm{S})$ and $\mathrm{Ni} / \mathrm{Al}(\mathrm{Cl})$ were analyzed by X-ray diffractometer to check crystalline phases of nickel particles depending on their metal precursor after drying treatment at $110{ }^{\circ} \mathrm{C}$ for $12 \mathrm{~h}$ and calcination at $500{ }^{\circ} \mathrm{C}$ for $1 \mathrm{~h}$. Figure 1 describes the $X$-ray diffractograms of the obtained catalysts before methanation process. The characteristic diffraction peaks of $\gamma-\mathrm{Al}_{2} \mathrm{O}_{3}$ appeared at $53.55^{\circ}$ and $79.59^{\circ}$, and $\mathrm{NiO}$ at $43.45^{\circ}, 50.63^{\circ}$ and $74.43^{\circ}$ for the three fresh catalysts. It was known that when nickel methanation catalyst was prepared by the impregnation-coprecipitation method, there were no nickel aluminate 
species, which were inactive catalytically and nonreducible, in the catalysts [3]. This data proved that the strong chemical interaction between metal catalyst and $\gamma \mathrm{Al}_{2} \mathrm{O}_{3}$ support material did not occur during the present catalyst preparation condition $[5,14,16]$. Intensity of the strongest peak at $50.63^{\circ}$ of $\mathrm{NiO}$ species in $\mathrm{Ni} / \mathrm{Al}(\mathrm{N})$ was higher compared to other catalysts, even though their nickel contents were similar. It might suggest the low crystallinity of nickel oxides in Ni/AI (S) and Ni/Al (Cl) catalysts.

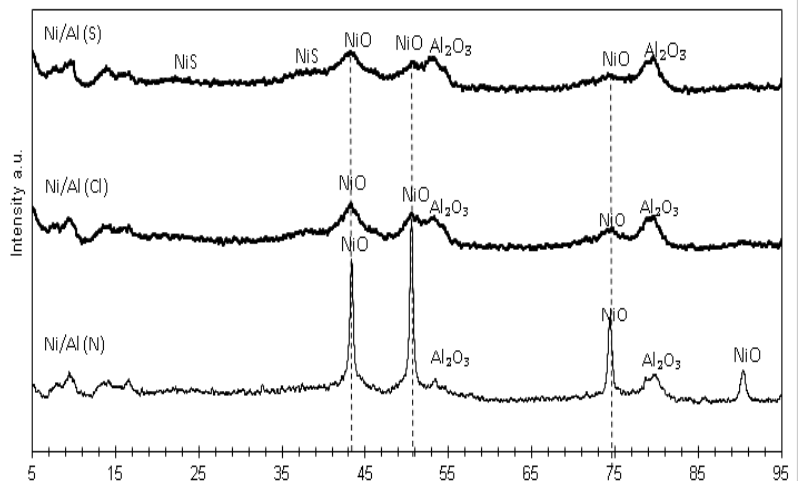

Fig. 1. X-ray diffractograms of the obtained catalysts of $\mathrm{Ni} / \mathrm{Al}(\mathrm{N}), \mathrm{Ni} / \mathrm{Al}(\mathrm{S})$ and $\mathrm{Ni} / \mathrm{Al}(\mathrm{Cl})$

Table 2 shows surface areas of the obtained fresh catalysts. It was observed that there were no significant differences between the values of catalyst surface areas. These data suggested, when catalyst loading method and catalyst support were same, nickel precursor type did not affect textural properties of the catalysts.

Table 2. BET surface areas of the obtained catalysts of $\mathrm{Ni} / \mathrm{Al}(\mathrm{N}), \mathrm{Ni} / \mathrm{Al}(\mathrm{S})$ and $\mathrm{Ni} / \mathrm{Al}(\mathrm{Cl})$

\begin{tabular}{cc}
\hline Catalyst code & Surface area, $\mathrm{m}^{2} \mathrm{~g}^{-1}$ \\
\hline $\mathrm{Ni} / \mathrm{Al}(\mathrm{N})$ & 130.6 \\
$\mathrm{Ni} / \mathrm{Al}(\mathrm{S})$ & 119.7 \\
$\mathrm{Ni} / \mathrm{Al}(\mathrm{Cl})$ & 127.8 \\
$\gamma-\mathrm{Al}_{2} \mathrm{O}_{3}$ & 176.5 \\
\hline
\end{tabular}

Activities of the obtained catalysts prepared by using various nickel salts as precursors were tested at the reaction temperature of $350{ }^{\circ} \mathrm{C}$ under the syngas pressure of $3 \mathrm{~atm}$. Catalyst activity was evaluated using by the parameters of $\mathrm{CO}$ conversion, $\mathrm{CH}_{4}$ selectivity and $\mathrm{CH}_{4}$ yield in a graph of those parameters versus reaction time in order to compare their instantaneous rates $[25,26]$.

$$
\mathrm{CO}+3 \mathrm{H}_{2} \rightarrow \mathrm{CH}_{4}+\mathrm{H}_{2} \mathrm{O} \quad \Delta \mathrm{H}=-206 \mathrm{~kJ} / \mathrm{mol}
$$

Carbon monoxide methanation is an exothermic reaction. The conversion of carbon monoxide is referred to as CO methanation (Eq. 1). Four mole of feed gases produces two mole of product, consequently reactant volume decreases 2 times and thermodynamically, low temperature and high pressure favor the methane production $[5,18]$.

$$
\mathrm{CO}+\mathrm{H}_{2} \mathrm{O} \rightarrow \mathrm{CO}_{2}+\mathrm{H}_{2}
$$

Moreover, due to the produced water, a water-gas shift reaction (Eq. 2) accompanies the $\mathrm{CO}$ methanation reaction using nickel catalysts in practical operation to produce a by-product of $\mathrm{CO}_{2}$ [19 - 22]. Feed gas contains $25 \%$ of $\mathrm{CO}$ and $75 \%$ of $\mathrm{H}_{2}$.

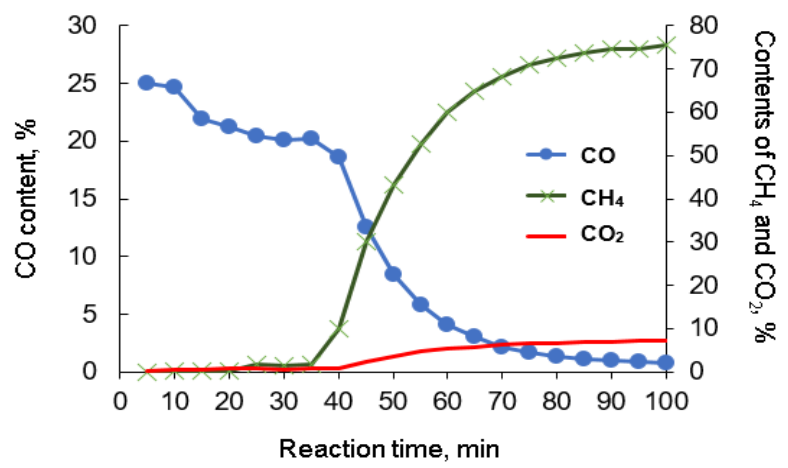

Fig. 2. $\mathrm{CO}, \mathrm{CH}_{4}$ and $\mathrm{CO}_{2}$ contents during methanation synthesis with the $\mathrm{Ni} / \mathrm{Al}(\mathrm{N})$ catalyst

As shown in Figure 2, the $\mathrm{Ni} / \mathrm{Al}(\mathrm{N})$ catalyst converts almost fully the carbon monoxide into methane. In the end of reaction, the content of CO was only $0.8 \%$ in product gas. It was known also that some part of $\mathrm{CO}$ gas was expended to produce $\mathrm{CO}_{2}$ because of a watergas shift reaction. However, the concentration of $\mathrm{CO}_{2}$ was approximately $7.1 \%$ in the product gas. Catalyst activity of the $\mathrm{Ni} / \mathrm{Al}(\mathrm{N})$ catalyst was compared with those of $\mathrm{Ni} / \mathrm{Al}(\mathrm{S})$ and $\mathrm{Ni} / \mathrm{Al}(\mathrm{Cl})$ in Figures 3(a) and 3(b). CO conversion with time over catalysts prepared from different precursors was presented in Figure $3(a)$. From this figure, it could be seen that within the tested time, CO conversion increased with time significantly for $\mathrm{Ni} / \mathrm{Al}(\mathrm{N})$ and $\mathrm{Ni} / \mathrm{Al}(\mathrm{Cl})$ catalysts, however $\mathrm{CO}$ conversion was very small and slowly increased for the $\mathrm{Ni} / \mathrm{Al}(\mathrm{S})$. The methane selectivity had a similar tendency with the CO conversion for every catalyst with reaction time. Thus, an effect of catalyst precursor on the methanation performance could be summarized in the order of: $\mathrm{Ni} / \mathrm{Al}(\mathrm{N}) \approx \mathrm{Ni} / \mathrm{Al}$ $(\mathrm{Cl})>\mathrm{Ni} / \mathrm{Al}(\mathrm{S})$. These results indicated that the nitrate and chloride salts were good precursors than sulfate based on activity consideration. However, chloride precursor is unfavorable environmentally because of a persistent organics emission source, therefore it was assumed that nickel nitrate was the best candidate for methanation catalyst precursor [22-24]. According to the characterization results of fresh catalysts (Table 1, 2 

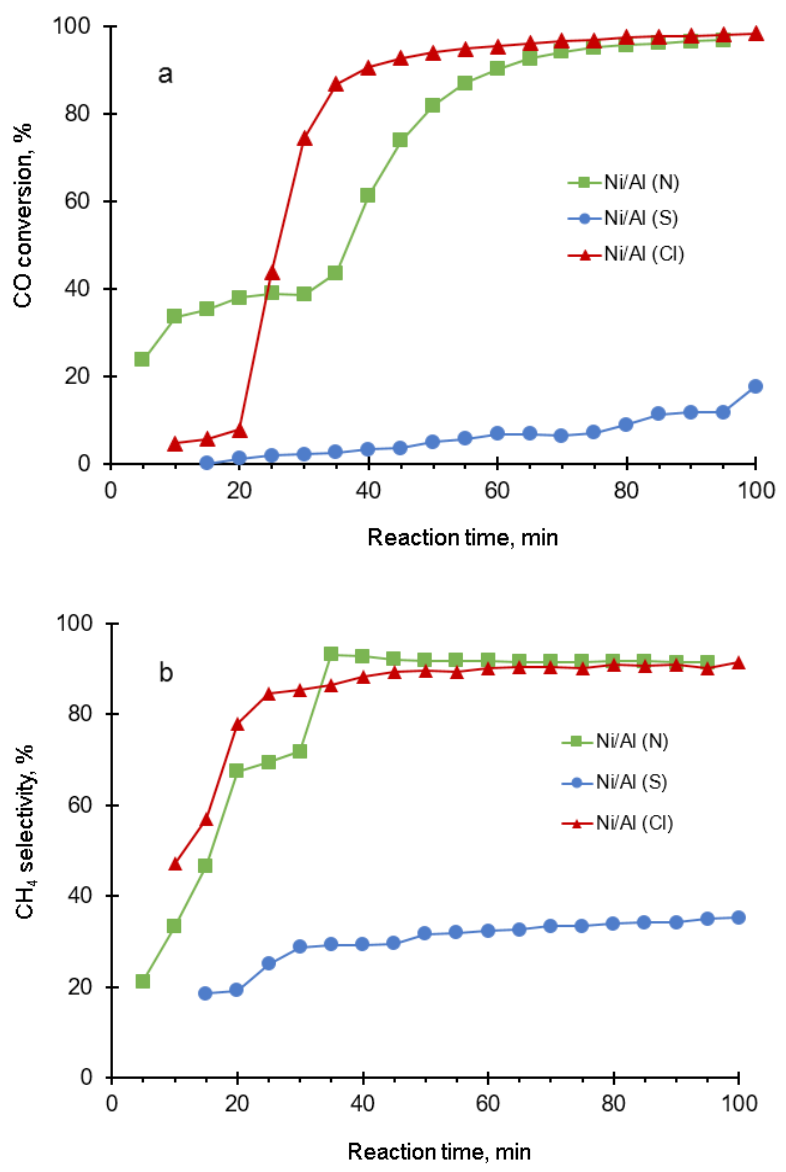

Fig. 3(a) and (b). CO conversion and methane selectivity obtained during the synthesis with the catalysts prepared from different metal precursors

and Figure 1), no significant differences were observed for the properties of three fresh catalysts. Moreover, the catalysts contained similar amounts of nickel metal species, and their surface areas were almost same. Though the catalysts were prepared using the same method of impregnation-co-precipitation, the only catalytic performance of $\mathrm{Ni} / \mathrm{Al}$ (S) was very low [24]. In order to examine a possible residual sulfur effect on catalytic activity, total sulfur of fresh catalysts were determined. Table 2 exhibited that the Ni/Al (S) contained $0.45 \mathrm{wt} \%$ of sulfur, whereas the sulfur contents of other catalysts were lower than the detection limit of a weight difference method $(<0.10$ wt $\%)$. Based on these results, we could conclude that a residual sulfur in the precipitate from sulfate precursor could not be removed fully by the same washing procedure as that for $\mathrm{Ni} / \mathrm{Al}(\mathrm{N})$ and $\mathrm{Ni} / \mathrm{Al}(\mathrm{Cl})$ catalysts. Therefore, active nickel surface of the $\mathrm{Ni} / \mathrm{Al}(\mathrm{S})$ was covered by sulfur to generate NiS film on catalyst perhaps after catalyst calcination, because no bulky sulfided species were detected in the Ni/Al (S) as showing in Figure 1. Again it was considered that the nitrate precursor was the most convenient choice for the preparation of methanation catalyst.

X-ray diffraction analysis of the used $\mathrm{Ni} / \mathrm{Al}(\mathrm{N})$
Table 2. Sulfur contents in the obtained catalysts of $\mathrm{Ni} / \mathrm{Al}(\mathrm{N}), \mathrm{Ni} / \mathrm{Al}(\mathrm{S})$ and $\mathrm{Ni} / \mathrm{Al}(\mathrm{Cl})$

\begin{tabular}{lc}
\hline Catalyst code & Total sulfur, wt \% \\
\hline $\mathrm{Ni} / \mathrm{Al}(\mathrm{N})$ & $<0.10$ \\
$\mathrm{Ni} / \mathrm{Al}(\mathrm{S})$ & 0.45 \\
$\mathrm{Ni} / \mathrm{Al}(\mathrm{Cl})$ & $<0.10$ \\
\hline
\end{tabular}

and $\mathrm{Ni} / \mathrm{Al}$ (S) catalysts after methanation for $1 \mathrm{~h}$ described an existence of unreduced $\mathrm{NiO}$ species in the catalyst which was prepared by a sulfate precursor. As shown in Figure 4, it was also identified that crystallinity of metallic $\mathrm{Ni}$ was sharp in the $\mathrm{Ni}$ / $\mathrm{Al}(\mathrm{N})$, and the main peaks of $\mathrm{X}$-ray diffraction were for $\mathrm{Ni}$ at around $52.1^{\circ}, 60.9^{\circ}$ and $91.7^{\circ}$.

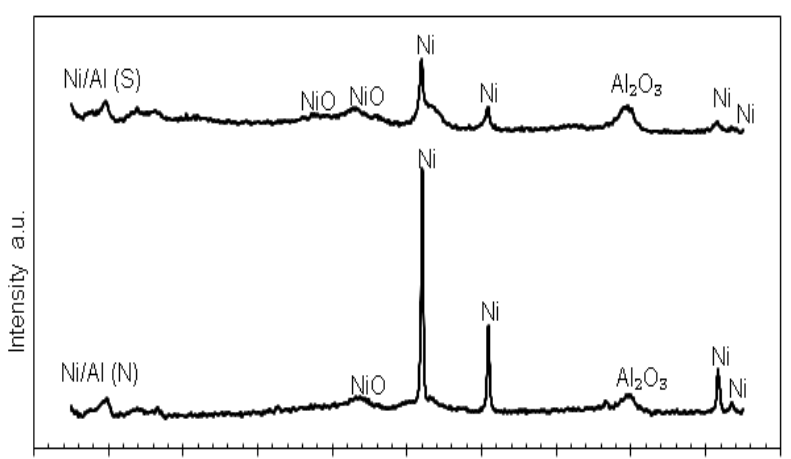

Fig. 4. X-ray diffractograms of the $\mathrm{Ni} / \mathrm{Al}(\mathrm{N})$ and $\mathrm{Ni} / \mathrm{Al}(\mathrm{S})$ catalysts after methanation for $1 \mathrm{~h}$

From Figure 4, it was concluded that the sharp peaks of metallic nickel species represented more amount of reduced nickel in the $\mathrm{Ni} / \mathrm{Al}(\mathrm{N})$. The $\mathrm{Ni} / \mathrm{Al}(\mathrm{N})$ catalyst gave sharp peaks of metallic nickel after methanation, even though only oxide type of nickel were observed before reaction (Figure 1). Therefore, nickel catalyst precursor of nitrate was able to produce high density of reducible $\mathrm{NiO}$ species, which eventually generated highly active Ni particles after hydrogen activation, on the surface of $\gamma \mathrm{Al}_{2} \mathrm{O}_{3}$ support.

Effect of catalyst activation temperature on methanation activity: Catalytic activities of the catalyst prepared by the nitrate precursor for $\mathrm{CO}$ methanation as a function of activation temperature are shown in Figure 5(a) and (b). Methanation condition was not changed and kept at the reaction temperature of $350^{\circ} \mathrm{C}$, in the pressure of 3 atmosphere for $1 \mathrm{~h}$. The GHSV of feed $\mathrm{H}_{2}$ and $\mathrm{CO}$ gases was $3000 \mathrm{~h}^{-1}$. Prior methanation, the $\mathrm{Ni} / \mathrm{Al}(\mathrm{N})$ catalyst was reduced by pure $\mathrm{H}_{2}$ gas with a flow rate of $13 \mathrm{ml} \cdot \mathrm{min}^{-1}$ for $60 \mathrm{~min}$ to prepare active $\mathrm{Ni}$ phase in a catalyst for $\mathrm{CO}$ methanation.

As seen from Figure 5(a) and (b), CO conversion occurred at the initial reaction time of $5 \mathrm{~min}$ on the $\mathrm{Ni} / \mathrm{Al}(\mathrm{N})$ catalyst, which was activated at $400{ }^{\circ} \mathrm{C}$ by pure hydrogen. In the temperature range of 116- 

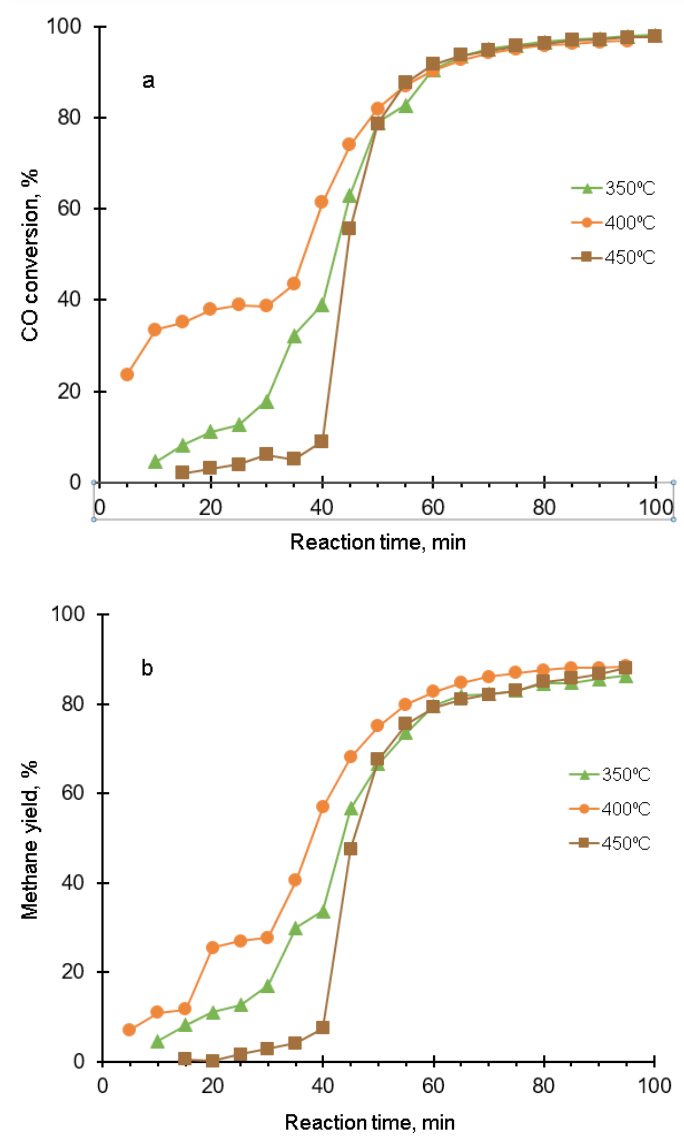

Fig. 5(a) and (b). CO conversion and methane selectivity during synthesis with the $\mathrm{Ni} / \mathrm{Al}(\mathrm{N})$ catalysts activated at the temperature of $350^{\circ} \mathrm{C}, 400^{\circ} \mathrm{C}, 450^{\circ} \mathrm{C}$ prior methanation synthesis

$305^{\circ} \mathrm{C}$ (corresponding to reaction time of 20-40 min), $\mathrm{CO}$ conversion and $\mathrm{CH}_{4}$ yield gave an evident upward trends with the increase of reaction temperature for the $\mathrm{Ni} / \mathrm{Al}(\mathrm{N})$ activated at $400{ }^{\circ} \mathrm{C}$, however at the same temperature trend $\mathrm{CO}$ conversion on the catalyst, which was activated at $350^{\circ} \mathrm{C}$ or $450^{\circ} \mathrm{C}$, started around after 30-40 min of synthesis. Therefore, as shown in Figure $5(\mathrm{a})$ and $(\mathrm{b})$, the $\mathrm{Ni} / \mathrm{Al}(\mathrm{N})$ catalyst, which was activated at $400{ }^{\circ} \mathrm{C}$, exhibited the highest $\mathrm{CO}$ conversion and $\mathrm{CH}_{4}$ yield. In present study, methanation temperature reached to the designated $350{ }^{\circ} \mathrm{C}$ after $45 \mathrm{~min}$ of reaction. Table 3 compared the specific performance of three $\mathrm{Ni} / \mathrm{Al}(\mathrm{N})$ catalysts, which were activated at

Table 3. Comparison of $\mathrm{CO}$ methanation performance for three $\mathrm{Ni} / \mathrm{Al}(\mathrm{N})$ catalysts activated at different temperatures, \%

\begin{tabular}{cccc}
\hline $\begin{array}{c}\text { Activation } \\
\text { temperature }\end{array}$ & $\begin{array}{c}\mathrm{CO} \\
\text { conversion }\end{array}$ & $\begin{array}{c}\mathrm{CH}_{4} \\
\text { selectivity }\end{array}$ & $\begin{array}{c}\mathrm{CO}_{2} \\
\text { selectivity }\end{array}$ \\
\hline $350^{\circ} \mathrm{C}$ & 63.00 & 86.46 & 0.14 \\
$400^{\circ} \mathrm{C}$ & 73.91 & 92.07 & 0.07 \\
$450^{\circ} \mathrm{C}$ & 55.51 & 85.75 & 0.10 \\
\hline
\end{tabular}

$350^{\circ} \mathrm{C}, 400^{\circ} \mathrm{C}$ or $450{ }^{\circ} \mathrm{C}$, at the reaction time of 45 min in $\mathrm{CO}$ methanation.

As showing in Table 3, the $\mathrm{Ni} / \mathrm{Al}(\mathrm{N})$ catalyst activated at $400{ }^{\circ} \mathrm{C}$ gave the highest $\mathrm{CO}$ conversion, $\mathrm{CH}_{4}$ selectivity and the lowest $\mathrm{CO}_{2}$ selectivity among the catalysts activated at three different temperature. This result clarified an appropriate activation temperature of the $\mathrm{Ni} / \mathrm{Al}(\mathrm{N})$.

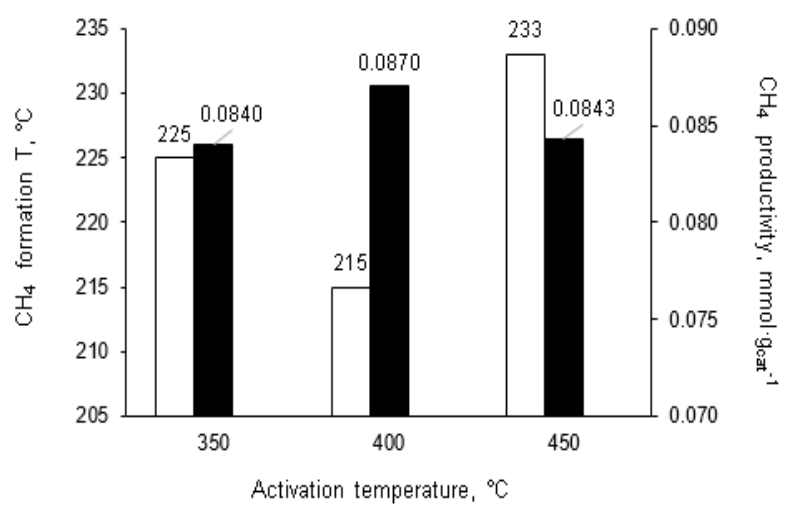

Fig. 6. $\mathrm{CH}_{4}$ formation $\mathrm{T}$ (black) and $\mathrm{CH}_{4}$ productivity (white) during the synthesis with the $\mathrm{Ni} / \mathrm{Al}(\mathrm{N})$ catalysts activated at the temperatures of $350^{\circ} \mathrm{C}$, $400{ }^{\circ} \mathrm{C}$ and $450{ }^{\circ} \mathrm{C}$ prior methanation synthesis

Figure 6 shows the initial temperatures of $\mathrm{CH}_{4}$ formation and the $\mathrm{CH}_{4}$ total productivities of three Ni/Al (N) catalysts, which were activated at $350^{\circ} \mathrm{C}, 400^{\circ} \mathrm{C}$ or $450^{\circ} \mathrm{C}$. The $\mathrm{CH}_{4}$ total productivity was calculated by a sum of produced $\mathrm{CH}_{4}$ amount per unit of catalyst weight for $1 \mathrm{~h}$ methanation. The performance of three catalysts were tested under the same conditions of methanation process. It was known that an initial temperature to form methane by the $\mathrm{Ni} / \mathrm{Al}(\mathrm{N})$ catalyst activated at $400{ }^{\circ} \mathrm{C}$ was the lowest at $215^{\circ} \mathrm{C}$, and it produced the highest amount of methane $\left(0.087 \mathrm{mmol} \cdot \mathrm{g}^{-1}\right.$ cat $)$ for 1 $\mathrm{h}$ methanation among three catalysts. However, the catalyst, which was activated at $450{ }^{\circ} \mathrm{C}$, produced methane from the temperature of $233^{\circ} \mathrm{C}$. It might be related to catalyst agglomeration during hydrogen reduction at very high temperature. Moreover, an initial temperature to form methane by the catalyst activated at $350{ }^{\circ} \mathrm{C}$ was not so high $\left(225^{\circ} \mathrm{C}\right)$, but it produced the smaller amount of methane in comparison with the catalyst activated at $400^{\circ} \mathrm{C}$.

\section{CONCLUSION}

Effects of precursor type of nickel metal and catalyst activation temperature on methanation performance were tested at the temperature of $350^{\circ} \mathrm{C}$, in the pressure of $3 \mathrm{~atm}$ of $\mathrm{H}_{2}$ :CO syngas with a GSHV of $3000 \mathrm{~h}^{-1}$.

The Ni/Al (N), Ni/Al (S) and Ni/Al (Cl) catalysts, which were prepared using by different precursors of nickel nitrate, sulfate and chloride salts, provided the $\mathrm{CH}_{4}$ selectivity of $93 \%, 18 \%$ and $91 \%$, respectively. 
An effect of the catalyst precursor on methanation performance could be placed in the order of: $\mathrm{Ni} / \mathrm{Al}(\mathrm{N})$ $\approx \mathrm{Ni} / \mathrm{Al}(\mathrm{Cl})>\mathrm{Ni} / \mathrm{Al}(\mathrm{S})$. Although the Ni/Al $(\mathrm{S})$ catalyst contained a similar amount of nickel, and had the same textural properties to other two catalysts, it contained a residual sulfur of $0.45 \%$. The low activity of the Ni/ $\mathrm{Al}(\mathrm{S})$ catalyst was caused due to the active surface contamination by the remained sulfur from sulfate precursor. The catalyst activated at $400{ }^{\circ} \mathrm{C}$ produced the highest $\mathrm{CH}_{4}$ productivity of $0.087 \mathrm{mmol} \cdot \mathrm{g}^{-1}$ cat for the duration of $1 \mathrm{~h}$ reaction; and its initial temperature of methane formation was the lowest of $215^{\circ} \mathrm{C}$ among the catalysts activated at different temperatures.

\section{ACKNOWLEDGEMENTS}

The authors gratefully acknowledge the financial supports from the Advanced Research Fund of National University of Mongolia, the MJEED Project and the Project of Science and Technology Foundation of Mongolia.

\section{REFERENCES}

1. Guo C., Wu Y., Qin H., Zhang J. (2014) CO methanation over $\mathrm{ZrO}_{2} / \mathrm{Al}_{2} \mathrm{O}_{3}$ supported $\mathrm{Ni}$ catalysts: A comprehensive study. Fuel Processing Technology, 124, 61-64. doi:10.1016/j. fuproc.2014.02.017

2. Huang Y., Wang J., Liu Z., Lin G., Zhang H. et al. (2013) Highly efficient $\mathrm{Ni}-\mathrm{ZrO}_{2}$ catalyst doped with $\mathrm{Yb}_{2} \mathrm{O}_{3}$ for co-methanation of $\mathrm{CO}$ and $\mathrm{CO}_{2}$. Applied Catalysis A: General, 466, 300-306. doi:10.1016/j. apcata.2013.06.021

3. Muhlen H.J., Sowa F. (1993) Comparison of the gasification behaviour of a West and East German brown coal. Fuel Processing Technology, 36, 185191. doi:10.1016/0378-3820(93)90026-z

4. Battulga B., Galindiv O., Byambajav E., (2018) Carbon monoxide methanation: Effect of catalyst preparation method. Journal of Mongolian Chemical Association. (Submitted).

5. Ronsch S., Schneider J., Matthischke S., Schluter M. et al. (2016) Review on methanation - From fundamentals to current projects. Fuel, 166, 276296. doi:10.1016/j.fuel.2015.10.111

6. Xiong J., Dong X., Song Y., Dong Y. et al. (2013) A high performance $\mathrm{Ru}-\mathrm{ZrO}_{2}$ /carbon nano tubes $\mathrm{Ni}$ foam composite catalyst for selective $\mathrm{CO}$ methanation. Journal of Power Sources, 242, 132136. doi:10.1016/j.jpowsour.2013.05.084

7. Yang X., Lu H., Gao G., Wang J., Han C. et al. (2014) Metal ( Fe, Co, Ce or La ) doped nickel catalyst supported on $\mathrm{ZrO}_{2}$ modified mesoporous clays for $\mathrm{CO}$ and $\mathrm{CO}_{2}$ methanation. Fuel, 183, 335344. doi:10.1016/j.fuel.2016.06.084

8. Zhu H., Razzaq R., Jiang L., Li C. et al. (2012) Low-tempperature methanation of $\mathrm{CO}$ in coke oven gas using single nanosized $\mathrm{Co}_{3} \mathrm{O}_{4}$. Catalysis Communications, 23, 43-47. doi:10.1016/j.

\section{catcom.2012.02.029}

9. Razzaq R., Zhu H., Jiang L., Li C., Zhang S. et al. (2013) Catalytic methanation of $\mathrm{CO}$ and $\mathrm{CO}_{2}$ in coke oven gas over $\mathrm{Ni}-\mathrm{Co} / \mathrm{ZrO}_{2}-\mathrm{CeO}_{2}$. Industrial and Engineering Chemistry Research, 52, 22472256. doi:10.1021/ie301399z

10. Ren J., Qin X., Yang J.Z., Guo H.L. et al. (2015) Methanation of carbon dioxide over Ni-M/ZrO $(\mathrm{M}=$ $\mathrm{Fe}, \mathrm{Co}, \mathrm{Cu}$ ) catalysts: Effect of addition of a second metal. Fuel Processing Technology, 137, 204-211. doi:10.1016/j.fuproc.2015.04.022

11. Teoh W.Y., Doronkin D.E., Beh G.K., Dreyer J.A.H. et al. (2015) Methanation of carbon monoxide over promoted flame-synthesized cobalt clusters stabilized in zirconia matrix. Journal of Catalysis, 326, 182-193. doi:10.1016/j.jcat.2015.03.014

12. Dong Y., Xiong J., Dong X., Song Y. et al. (2013) A high performance $\mathrm{Ru} \mathrm{ZrO}_{2}$ /carbon nanotubese $\mathrm{Ni}$ foam composite catalyst for selective $\mathrm{CO}$ methanation. Journal of Power Sources, 242, 132136. doi:10.1016/j.jpowsour.2013.05.084

13. Song I.K., Hwang S., Lee J., Hong U.G., Jung J.C. et al. (2012) Hydrogenation of carbon monoxide to methane over mesoporous nickel-M-alumina $(\mathrm{M}=\mathrm{Fe}, \mathrm{Ni}, \mathrm{Co}, \mathrm{Ce}$, and $\mathrm{La})$ xerogel catalysts. Journal of Industrial and Engineering Chemistry, 18, 243-248. doi:10.1016/j.jiec.2011.11.026

14. Gidai N.A., Loc L.C., Huan N.M., Thoang H.S. et al. (2016) Kinetics of carbon monoxide methanation on nickel catalysts. Kinetics and Catalysis, 1, 5971. doi:10.1134/S0023158412030093

15. Urasaki K., Tanpo Y., Nagashima Y., Kikuchi R. et al. (2013) Effects of preparation conditions of $\mathrm{Ni} /$ $\mathrm{TiO}_{2}$ catalysts for selective $\mathrm{CO}$ methanation in the reformate gas. Applied Catalysis A: General, 452, 174-178.

16. Shen D., Cheng C., Xiao R., Wu C. et al. (2017) Methanation of syngas $\left(\mathrm{H}_{2} / \mathrm{CO}\right)$ over the difference Ni-based catalysts. Fuel, 189, 419-427. doi:10.1016/j.fuel.2016.10.122

17. Cheng Y., Liu Z., Chu B., Zhai X., Jin Y. et al. (2012) Total methanation of syngas to synthetic natural gas ovr Ni catalyst in a micro-channel reactor. Fuel, 95, 599-605. doi:10.1016/j.fuel.2011.12.045

18. Schilidhauer T.J., Kopyscinski J., Biollaz S.M.A. (2010) Production of synthetic natural gas (SNG) from coal and dry biomass - A technology review from 1950 to 2009. Fuel, 89, 1763-1783. doi:10.1016/j.fuel.2010.01.027

19. Zhang J., Han Y., Bai Y., Zhang Q. et al. (2014) Low-temperature methanation of syngas in slurry phase over $\mathrm{Zr}$-doped $\mathrm{Ni} / \gamma-\mathrm{Al}_{2} \mathrm{O}_{3}$ catalysts prepared using different methods. Fuel, 132, 211-218. doi:10.1016/i.fuel.2014.04.085

20. Lu B., Kawamoto K. (2013) Preparation of the highly loaded and well-dispersed NiO/SBA-15 for methanation of producer gas. Fuel, 103, 669-704. doi:10.1016/j.fuel.2012.09.009 
21. Cai M., Wen J., Chu W., Cheng X., Li Z. et al. (2011) Methanation of carbon dioxide on $\mathrm{Ni} / \mathrm{ZrO}_{2}-$ catalysts: Effects of $\mathrm{ZrO}_{2}$ promoter and preparation method of novel $\mathrm{ZrO}_{2}$-carrier. Journal of Natural Gas Chemistry, 20, 318-324. doi:10.1016/s10039953(10)60187-9

22. Chamarthi K., Srikanth P., (2009) Effect of anion on the homogeneous precipitation of precursors and their thermal decomposition to zinc oxide. Journal of Alloys and Compounds, 486, 677-684. doi:10.1016/j.jallcom.2009.07.031

23. Barrientos J., Lualdi M., Boutonnet M., Järås M. (2014), Deactivation of supported nickel catalysts during $\mathrm{CO}$ methanation. Applied Catalysis A: General, 486, 143-149. doi:10.1016/j. apcata.2014.08.021
24. Yu Z., Hu X., Jia P., Zhang Z., Dong D. et al. (2018), Steam reforming of acetic acid over nickel-based catalysts: The intrinsic effects of nickel precursors on behaviors of nickel catalysts. Applied Catalysis B: Environmental, 237, 538-553. doi:10.1016/j. apcatb.2018.06.020

25. Tian D., Liu Z., Li D., Shi H., Pan W. et al. (2013), Bimetallic Ni-Fe total-methanation catalyst for the production of substitute natural gas under high pressure. Fuel, 104, 224-229. doi:10.1016/j. $\underline{\text { fuel.2012.08.033 }}$

26. He Z., Wang X., Gao S., Xiao T. (2015), Effect of reaction variables on $\mathrm{CO}$ methanation process over $\mathrm{NiO}-\mathrm{La}_{2} \mathrm{O}_{3}-\mathrm{MgO} / \mathrm{Al}_{2} \mathrm{O}_{3}$ catalyst for coal to synthetic natural gas. Appl. Petrochem. Res., 5, 413-417. $\underline{\text { doi:10.1007/s13203-015-0127-9 }}$ 